Журнал «Герспективитаінноваціїнауки»

(Серія «Педагогіка», Серія «Гиихологія», Серія«Медицина»

№5(5) 2021

УДК 378:37.032

https://doi.org/10.52058/2786-4952-2021-5(5)-354-363

Касьянова Олена Миколаївна доктор педагогічних наук, професор, завідувач кафедри педагогіки, філософії та мовної підготовки, Харківська медична академія післядипломної освіти, вул. Амосова, 58, м. Харків, 61176, тел.:(057) 711-35-56, https://orcid.org/0000-0003-3165-5440

Квасник Ольга Віталіївна кандидат педагогічних наук, доцент кафедри педагогіки, філософії та мовної підготовки, Харківська медична академія післядипломної освіти, м. Харків, вул. Амосова, 58, м. Харків, 61176, тел.: (057) 711-35-56, e-mail: kvasnykov@ukr.net, https://orcid.org/0000-0001-9911-7337

\title{
ОСОБЛИВОСТІ ВПРОВАДЖЕННЯ ОСНОВ ІННОВАЦІЙНОЇ ПЕДАГОГІКИ ДО ОСВІТНЬОГО ПРОЦЕСУ ЗДОБУВАЧІВ ОСВІТНЬО- НАУКОВОГО РІВНЯ ДОКТОР ФІЛОСОФІї
}

Анотація. Розглянуто основні умови, створені для здобувачів освітньонаукового рівня доктор філософії на теренах українського соціокультурного простору. Основним фактором позитивних зрушень у бік покращення умов освітнього процесу $є$ роль органів управління, зокрема Міністерства освіти та науки України, Національного агентства із забезпечення якості освіти та інших, які інтенсивно працюють над створенням нормативно-правового сектору щодо впровадження інновацій, підтримки молодих вчених та їхніх досліджень.

Обгрунтовано основні вимоги від здобувачів як ініціаторів та учасників процесів стимулювання, створення, розвитку, застосування інновацій у контексті прогресивних трансформацій інформаційного простору.

Одними із основних особливостей впровадження основ інноваційної педагогіки до освітнього процесу $\epsilon$ навчальний план та освітньо-професійна програма, індивідуальний план наукової роботи, порядок підготовки здобувачів вищої освіти ступеня доктора філософії та доктора наук у закладах вищої освіти, де зазначено основні компетентності здобувачів. Зокрема на прикладі освітньо-професійних програм Харківської медичної академії післядипломної освіти розглянуто основні з них, що зазначають про потребу у синергії освіти і науки, у залученні освітнього процесу до формування i вдосконалення структури особистості здобувача, до розбудови інноваційних тенденцій сучасності. Отже, впровадження інноваційної педагогіки до освітньої програми здобувачів третього освітнього рівня доктора філософії Харківської академії післядипломної освіти $є$ закономірним, виваженим i обгрунтованим.

Розкрито особливості впровадження основ інноваційної педагогіки до 
освітнього процесу, зокрема майбутніх докторів філософії. Показано перспективи щодо модернізації освітньо-наукового простору з урахуванням результатів вивчення дисципліни інноваційна педагогіка.

Ключові слова: здобувачі освітньо-наукового рівня доктор філософії, інноваційна педагогіка, якість освіти, Харківська медична академія післядипломної освіти.

Kasyanova Olena Mykolaivna Doctor of Pedagogical Sciences, Professor, Head of the Department of Pedagogy, Philosophy and Language Training, Kharkiv Medical Academy of Postgraduate Education, Amosova St., 58, Kharkiv, 61176, tel.: (057) 711-35-56, https://orcid.org/0000-0003-3165-5440

Kvasnyk Olga Vitaliivna Candidate of Pedagogical Sciences, Associate Professor of the Department of Pedagogy, Philosophy and Language Training, Kharkiv Medical Academy of Postgraduate Education, Kharkiv, st. Amosova, 58, Kharkiv, 61176, tel $\therefore$ (057) 711-35-56, e-mail: kvasnykov@ukr.net, https://orcid.org/0000-0001-9911-7337

\section{PECULIARITIES OF INTRODUCTION OF FUNDAMENTALS OF INNOVATIVE PEDAGOGY INTO THE EDUCATIONAL PROCESS OF EDUCATIONAL AND SCIENTIFIC LEVEL STUDENTS DR. FILOSO}

Abstract. The main conditions created for the candidates of educational and scientific level of Doctor of Philosophy in the Ukrainian socio-cultural space are considered. The main factor in the positive changes towards improving the educational process is the role of governing bodies, including the Ministry of Education and Science of Ukraine, the National Agency for Quality Assurance in Education and others working intensively to create a legal sector to innovate, support young scientists and research.

The basic requirements from applicants as initiators and participants of processes of stimulation, creation, development, application of innovations in the context of progressive transformations of information space are substantiated.

One of the main features of introducing the basics of innovative pedagogy in the educational process is the curriculum and educational-professional program, individual plan of scientific work, the order of preparation of graduates of $\mathrm{PhD}$ and $\mathrm{PhD}$ in higher education institutions, which indicate the main competencies of applicants. In particular, on the example of educational and professional programs of Kharkiv Medical Academy of Postgraduate Education, the main ones are considered, indicating the need for synergy of education and science, involvement in the educational process to form and improve the personality structure of the applicant, to develop innovative trends. Thus, the introduction of innovative pedagogy in the educational program of students of the third educational level of Doctor of Philosophy of the Kharkiv Academy of Postgraduate Education is natural, balanced and justified. 
Features of introduction of bases of innovative pedagogics to educational process, in particular future doctors of philosophy are opened. Prospects for the modernization of educational and scientific space are shown, taking into account the results of studying the discipline of innovative pedagogy.

Keywords: educational and scientific level Doctor of Philosophy, Innovative Pedagogy, Quality of Education, Kharkiv Medical Academy of Postgraduate Education.

Постановка проблеми. Основним питанням для детального вивчення на сьогодні у галузі освіти $\epsilon$ iї якість. Безперечно, не можна визначити рівень ефективності навчального процесу без певних критеріїв, які були визначені і затвердженні на сьогодні двома провідними установами у сфері освіти: Міністерство освіти і науки, Національне агентство із питань забезпечення якості освіти. Серед критеріїв, що вказують на поєднання наукової діяльності, досліджень і навчання, можна визначити критерії 4 та 10 у контексті оцінювання якості освітньої програми [1].

Аналіз останніх досліджень та публікацій. У нормативно-правових актах законодавчого простору України, зокрема Закону України «Про інноваційну діяльність»; закону України «Про пріоритетні напрями інноваційної діяльності в Україні»; Положення Міністерства освіти і науки України «Про порядок здійснення інноваційної освітньої діяльності» зазначено коло дефініцій, що пов'язані передусім із інноваціями, їх розробкою, впровадженням, розповсюдженням, роллю вчених та здобувачів у цих процесах. Створено умови для прогресивних змін та розвитку інноваційних модернізацій у різних галузях знання, що вимагає формування готовності до розробки та впровадження інновацій, зокрема у контексті підготовки молодих учених, здобувачів освітнього рівня доктор філософії.

Аналіз останніх досліджень i публікацій. Питання змісту терміну інновація та готовності до інноваційної діяльності останнім часом вивчали вітчизняні та зарубіжні вчені: щодо змісту поняття інновація (Л. Даниленко, I. Підласий, В. Паламарчук, О. Савченко, О. Касьянова, тощо), історії дослідження та впровадження інновацій (І. Аносов, Л. Вовк, М. Кларін, О.Попова, підготовки педагогічних кадрів до впровадження нововведень до майбутньої інноваційної діяльності (І. Гавриш, І. Коновальчук, Л. Подимова, В. Сластьонін, С. Сисоєва та ін.).

Різноманітним аспектам професійної підготовки педагогічних кадрів до проєктування, створення інноваційних педагогічних технологій присвячено дослідження О. Андрусь, О. Гончарової, Т. Демиденко, Ю. Забіяко, Н. Івасів, Я. Мандрик, О. Павлика, В. Павленко, О. Поліщука, Т. Танько, Г. Троцко, Н. Мукан,О. Шапран та ін.

Досі малодослідженим $\epsilon$ питання забезпечення освітнього процесу освітніми компонентами, що забезпечують готовність до інноваційної діяльності, передання досвіду та продовження життєвого циклу своєї розробки, 
дослідження, інновації, залучення до наукової галузі світового та вітчизняного простору.

Мета статті. Мета нашого дослідження вивчити впровадження дисципліни інноваційна педагогіка до освітнього процесу здобувачів освітнього рівня доктор філософії Харківської медичної академії післядипломної освіти.

Виклад основного матеріалу. Необхідність забезпечувати ефективність освітнього процесу спонукає на виникнення потреби у готовності науковців до ситуацій невизначеності, до використання нових технологій та впровадження своїх інноваційних продуктів у життєдіяльність суспільства. В Україні створено нормативно-правові засади, що дають змогу діяти відповідно до норм функціонування, зокрема наукової галузі.

Один із основних законів «Закон України про інноваційну діяльність» декларує «створення умов для збереження, розвитку i використання вітчизняного науково-технічного та інноваційного потенціалу», а також вказує на нагальну потребу у «забезпеченні взаємодії науки, освіти, виробництва, фінансово-кредитної сфери у розвитку інноваційної діяльності», акцентує увагу на «інформаційному забезпеченні суб'єктів інноваційної діяльності; підготовці кадрів у сфері інноваційної діяльності» [2].

Серед основних пріоритетів інноваційності можна виділити нові знання, інноваційні освітні програми і проєкти, інші інтелектуальні продукти, які істотно поліпшують якість освіти, результативність тощо. Науковий освітній рівень спонукає до безпосередньої участі у процесах пов'язаних із інноваціями. Отже, здобуття наукового освітнього рівня передбачає оволодіння загальними та спеціальними компетентностями, зокрема такими, що сприяють продуктивному створенню нових ідей та вирішенню комплексних проблем у галузі професійної або дослідницько-інноваційної діяльності, допомагають оволодіти змістом науково-педагогічної діяльності тощо. Такий перелік необхідних здатностей повинен бути забезпечений систематичним продуктивним інструментом для ефективної реалізації та впровадження. Безперечно треба враховувати певний комплекс умов для використання такого інструменту. Однією із основних умов $\epsilon$ навчальний план та освітньопрофесійна програма, де перелік навчальних дисциплін має обсяг 30-60 кредитів Європейської кредитної трансферно-накопичувальної системи (далі ЄКТС). Ці важливі аспекти спонукають до формування здобувачем рівня доктор філософії «індивідуального навчального плану та індивідуального плану наукової роботи, які погоджуються 3 науковим керівником та затверджуються вченою радою закладу вищої освіти (наукової установи) протягом двох місяців із дня зарахування особи до аспірантури (ад’юнктури)»[3].

Наприклад, відповідно до ОПП підготовки доктор філософії в аспірантурі Харківської медичної академії післядипломної освіти з медичних наук за спеціальністю 228 педіатрія у спеціальних компететностях (СК7, СК8, СК 9) 
зазначено про потребу у синергії освіти і науки, у залученні освітнього процесу до формування і вдосконалення структури особистості здобувача. ОПП 222 медицина констатує наявність потреби у поєднанні освітньої та наукової діяльності здобувачів освітнього рівня доктор філософії (наприклад вміння впроваджувати наукові досягнення в навчальний процес, використовувати сучасні інформаційні технології для оптимізації процесу навчання тощо) $[7,8]$. Відповідно до порядку підготовки здобувачів вищої освіти ступеня доктора філософії та доктора наук у закладах вищої освіти (наукових установах) саме індивідуальний план наукової роботи є обов'язковим до виконання здобувачем відповідного ступеня i використовується для оцінювання успішності запланованої наукової роботи, його створення та виважене змістовне наповнення допоможуть активізувати та спрямувати наукову діяльність здобувача, спрямувати іiі на створення інновацій, активізують процеси «самості» особистості, зокрема самостійну роботу, самоконтроль тощо [3]. Сформувати навички планування, прогнозування, готовність до створення, впровадження інновацій, готовність до сприйняття нових явищ прогресу, передавання досвіду, формування наукових шкіл покликана інноватика i суміжні науки та освітні дисципліни. Тому впровадження інноваційної педагогіки до освітньої програми здобувачів третього освітнього рівня доктора філософії Харківської академії післядипломної освіти $є$ закономірним, виваженим і обгрунтованим.

Безперечно, система вищої освіти враховує інноваційність не лише у контексті симбіозу науки і освіти, але й під час напрацювання практично орієнтованих компетентностей. Наприклад враховуються тенденції сучасного прогресу у світовій науці, що забезпечує зміну усталених концепцій у контексті освітнього процесу, зокрема здобувачів третього освітнього рівня.

Затребуваність у популяризації інновацій підтверджується створенням низки положень, зокрема про затвердження Порядку підготовки здобувачів вищої освіти ступеня доктора філософії та доктора наук узакладах вищої освіти (наукових установах), де зазначено про підтримку наукових досліджень, можливість «представити наукові досягнення 3 узагальненням проведених самостійно оригінальних досліджень із отриманими науковими результатами, які забезпечують розв'язання важливої теоретичної або прикладної проблеми, мають загальнонаціональне або світове значення» [3, п. 44], які можливо здійснити завдяки участі у грантах, «стартапах», при підтримці Міністерства освіти і науки завдяки конкурсам та преміям, державним іменним стипендіям, та Національного фонду досліджень, створеного для розбудови мережі підтримки наукової діяльності та співробітництва з міжнародними фондами, донорами, інвесторами та науковими організаціями. Докладна інформація про умови залучення здобувачів до участі у розбудові наукового простору України та представлення іiі у світових наукових колах міститься на сайті Міністерства науки і освіти України в окремому розділі доступному за посиланням https://mon.gov.ua/ua/nauka/nauka/nacionalnij-fond-doslidzhen [4]. 
Проте на сайті не йдеться про шляхи формування та розвитку готовності здобувачів - майбутніх докторів філософії до сприйняття та впровадження інноваційного когнітивного контенту, стимуляцію ними подальшого циклу інновацій (зокрема формування послідовників, передання досвіду наукової діяльності тощо). Інноваційна педагогіка передбачає здобуття компетентностей щодо «оприлюднення результатів, забезпечення умов для їх реалізації у системі освіти» та науки [5, с. 33-34].

Фонд національних досліджень покликаний впливати на ефективність наукової діяльності молодих вчених за рахунок надання різних видів підтримки (премії, стипендії, гранти, конференції, затвердження концепції державної політики розвитку дослідницької інфраструктури, долучення до пріоритетних Європейських консорціумів дослідницьких інфраструктур (ERIC), розбудова Європейської Хмари Відкритої Науки (EOSC) разом із країнами Європи тощо) [6, с 21]. Проте в положенні не розкрито шляхи здійснення підготовки до інноваційної діяльності та розбудови освітнього простору для новаторів, тих хто творить науку та впроваджує іiі у соціокультурний простір. У контексті концепції безперервної освіти можемо говорити про необхідність оновлення компетентностей та потреби у циклічному підвищенні рівня взаємодії із інформаційним простором, тобто «тримати руку на пульсі» сучасного знання у своїй галузі та загальних світових новацій, бути обізнаним із інноваціями та вміти використати це знання у потрібний момент під час діяльності, адаптувати когнітивне особистісне поле до умов роботи тощо. У стратегічному плані розвитку також йдеться про державну підтримку щодо провадження інноваційної діяльності, зокрема українські інноватори отримують ii на провадження інноваційної діяльності.[ 6, с. 25].

Завдяки стратегічному плану розвитку забезпечується можливість інтенсивного симбіозу освіти і наукової діяльності, зокрема у п. 6.2.1.5. у контексті створення та функціонування на базі закладів вищої освіти та наукових установ функціонування ланцюга: стартап школа - акселератор інкубатор, а також у п. 6.3.1. йдеться про навчальні семінари, тренінгів що впливають на розвиток навичок здійснення інноваційної діяльності, у сфері менеджменту інноваційної діяльності, забезпечують підвищення кваліфікації фахівців інноваційної інфраструктури [ 6, с. 26]. Зате не приділено увагу набору освітніх компонент, які мають забезпечити готовність таких фахівців, а також дозволити формувати, розвивати , вдосконалювати зазначені навички.

3 огляду на запит державної політики у контексті розбудови наукового сектору до нормативних дисциплін здобувачів третього освітнього рівня доктор філософії Харківської медичної академії післядипломної освіти було запроваджено дисципліну інноваційна педагогіка, яка покликана забезпечити та доповнити їхню структуру особистості затребуваними компететностями, сформувати готовність до інноваційної діяльності, передбачену нормативноправовим сектором. Серед основних цілей дисципліни на особливу увагу у 
контексті викладених умов діяльності здобувачів третього освітнього рівня, а також підвищеної уваги до розбудови наукового сектору у тандемі із освітнім заслуговують такі: опанування уміннями проектування і реалізації авторських інноваційних ідей, узагальнення та творчого використання перспективного педагогічного досвіду; формування інноваційного педагогічного мислення, готовності до інноваційної педагогічної діяльності тощо.

Змістове наповнення інноваційної педагогіки забезпечує перспективи формування необхідних складових професійно-педагогічної діяльності молодого науковця. До Робочої програми дисципліни інноваційна педагогіка зокрема увійшли такі теми: Сучасні домінанти розвитку вищої та післядипломної медичної освіти, Управління інноваційною професійнопедагогічною діяльністю, Моделювання інноваційних технологій, Інноваційні технології у вищій медичні освіті тощо. Під час опанування модулями дисципліни здобувачі мають змогу втілити власне бачення інноваційних продуктів, представити розробки, дотичні до професійної спрямованості власного наукового дослідження, передбачити траєкторію розвитку та стадії життєвого циклу інновації та інше. Дисципліна має практико-професійну орієнтованість, що забезпечується передусім комплексом завдань для самостійної роботи за умови включеності викладача через систему консультацій із застосуванням інформаційних технологій та сучасних інформаційних засобів, зокрема щодо підтримки зворотнього зв'язку, наприклад спеціальних мережевних сервісів, спеціалізованих пошукових систем, месенджерів, соціальних мереж тощо. Здобувачі мали змогу спроєктувати власні розробки через призму специфіки наукового дослідження, практично апробувати за рахунок доповідей та представлення результатів роботи, зокрема й в аудиторії під час практик. Зокрема запропоновано організувати та провести тренінг, взяти участь у розігруванні ролей, стати учасниками педагогічного квесту, спробувати свої сили у командному інтенсиві та інше. Здобувачі активно розвивають компетентності, що пов'язані 3 інноваційною складовою, новітнім знанням, прогнозуванням діяльності 3 урахуванням вектору технічного та інформаційного прогресу, що доводять передусім результати рубіжного контролю, показуючи покращення результатів. Інноваційна педагогіка у контексті підготовки здобувачів третього освітнього рівня доктор філософії, окрім зміни показників компетентнісного характеру та інтенсивного сплетіння освітніх та наукових реалій у контексті загальної палітри умов, безперечно, впливає на світоглядну та ціннісну компоненти структури особистості, дозволяє охоплювати широкий часовий спектр за рахунок безперервності трансляції досвіду, наголошуючи на особистісних його проявах. Розуміння значущості трансформацій у соціокультурних парадигмальних контекстах дійсності допомагає здобувачам змінити ставлення до власної діяльності та досліджень, додає прагнення продовжити цикл життя винаходів через призму множинності трансляцій власного досвіду та тих методологічних основ, що брали участь у його 
формуванні. Створюється прогресивна канва для вдосконалення професіоналізму та конкурентоздатності завдяки особливому рівнобічному трикутнику (рис.1 ).

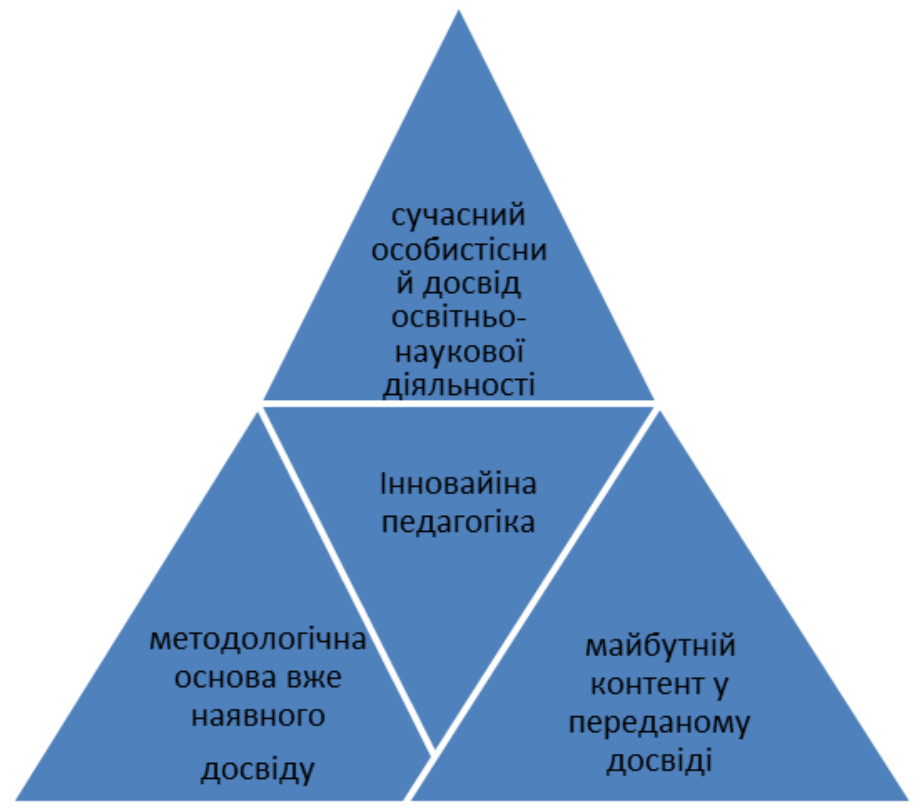

Puс. 1. Прогресивна площцина для вдосконалення професіоналізму та конкурентоздатності здобувачів

Треба враховувати певні відхилення, що будуть уповільнювати освітній процес, проте переваги запровадження цієї дисципліни, а також створені комфортні для цього умови, високий запит стейкхолдерів та здобувачів на гарантовані результати, що забезпечуються змістом дисципліни та освітнього процесу, звертають увагу на потенціал від функціонування інноваційної педагогіки у структурі навчальної програми, самого освітнього рівня та педагогічної думки в цілому.

Висновки. Система сучасного законодавства спрямована на політику синергетичного злиття освітньої та наукової галузей, що допоможе сформувати готовність до множинності перспектив, новітнього знання та інноваційності як однієї з важливих складових конкурентоспроможності та професіоналізму фахівця на будь-якому етапі функціонування у соціокультурному та інформаційному просторі. Така інтенсивна підтримка відповідних запорук сталого розвитку у контексті освітнього процесу та наукових досліджень стає підгрунтям для фундаментальної підготовки здобувачів освітнього-наукового рівня доктор філософії. За умови впровадження освітніх компонентів, що забезпечують удосконалення особистості професіонала, до освітніх програм зазначеного рівня, стратегічного розвитку держави у напрямі забезпечення всебічної підтримки молодим науковцям та дослідникам, авторам інновацій у різних галузях, співпраці із стейкхолдерами та закордонними організаціями, зокрема які надають фінансову підтримку, роботодавцями виступають, освітніми установами тощо, закономірною $є$ потреба у фундаментальному 
вимірі основ структури підготовки здобувача вказаного вище рівня та формуванні його готовності до різних рівнів інноваційної діяльності, багатоманіття іiі складових, яка може бути задоволена за рахунок впровадження дисципліни інноваційна педагогіка у розряд нормативних компонент освітньої програми.

Серед перспектив вивчення особливостей впровадження інноваційної педагогіки до освітніх програм другого освітнього рівня магістр, дослідження результатів впливу іï вивчення на особистість здобувачів освітньо-наукового рівня доктор філософії та на професіоналізм учасників освітнього процесу, авторів інновацій, учасників розбудови наукової думки України, на реалізацію стратегічних планів взаємодії міжрегіонального та міждержавного рівня.

\section{Лimepamypa:}

1. Рекомендації щодо застосування критерії оцінювання якості освітньої програми // Затверджено Національним агентством із забезпечення якості вищої освіти 17 листопада 2020 року: ТОВ «Український освітянський видавничий центр «Оріон»». - К. - 2020. - С. 66

2. Закон України «Про інноваційну діяльність» [Електронний ресурс] // Відомості Верховної Ради України. - 2002. - № 36. - Ст. 266. - Режим доступу: http://zakon4.rada.gov.ua/laws/show/40-15

3. Постанова Кабінету міністрів України «Про затвердження Порядку підготовки здобувачів вищої освіти ступеня доктора філософії та доктора наук у вищих навчальних закладах (наукових установах)» № 283 від 03.04.2019 [Електронний ресурс]. - Режим доступу: https://zakon.rada.gov.ua/laws/show/261-2016-\%D0\%BF\#Text

4. Міністерство освіти і науки України. Фонд національних досліджень. [Електронний pecypc]. - Режим доступу: https://mon.gov.ua/ua/nauka/nauka/nacionalnij-fond-doslidzhen

5. Ващенко Л. М. Управління інноваційними процесами в загальній середній освіті регіону : Монографія / Л. М. Ващенко. - К. : Видавниче об’єднання «Тираж». - 2005. - С. 380

6. Стратегічний план діяльності міністерства освіти і науки України до 2024 року від 19.12.2019 [Електронний ресурс]. - Режим доступу: https://mon.gov.ua/storage/app/media/ news/\%D0\%9D\%D0\%BE\%D0\%B2\%D0\%B8\%D0\%BD\%D0\%B8/2020/01/strat_plan_mon_2024.pdf

7. Освітньо-наукова програма підготовки докторів філософії в аспірантурі Харківської медичної академії післядипломної освіти 3 медичних наук за спеціальністю 222 Медицина [Електронний ресурс].

Режим доступу: https://drive.google.com/file/d/1MydGJkTM8cX5SGgt6CuUEmfA5tMHK3RI/view

8. Освітньо-наукова програма підготовки докторів філософії в аспірантурі Харківської медичної академії післядипломної освіти 3 медичних наук за спеціальністю 228 Педіатрія [Електронний ресурс]. - Режим доступу: https://drive.google.com/file/d/1JxULj_ f9JVLxRiE0x3AHwF6RSh0KsUn1/view

9. Касьянова О. М. Теоретико-методологічні основи інноваційної педагогіки / О. М. Касьянова, О. В. Квасник // Навчально-методичний посібник для самостійної роботи здобувачів вищої освіти ступеня доктор філософії з навчальної дисципліни «Інноваційна педагогіка» (змістовний модуль 1 частина 1). - Харків : ХМАПО. - 2021. - С. 38

\section{References:}

1. Rekomendaciï shhodo zastosuvannja kriteriï ocinjuvannja jakosti osvitn'ö̈ programi [Recommendations for the application of criteria for assessing the quality of the educational program]. (2020). TOV «Ukraïns'kij osvitjans'kij vidavnichij centr «Orion»». - K. [in Ukrainian]. 
2. Zakon Ukraïni «Pro innovacijnu dijal'nist'» [The Law “On Innovation”]. (n.d.). zakon.rada.gov.ua. Retrieved from http://zakon4.rada.gov.ua/laws/show/40-15 [in Ukrainian]

3. Postanova Kabinetu ministriv Ukraïni «Pro zatverdzhennja Porjadku pidgotovki zdobuvachiv vishhoï osviti stupenja doktora filosofiï ta doktora nauk u vishhih navchal'nih zakladah (naukovih ustanovah)» [Resolution of the Cabinet of Ministers of Ukraine "On approval of the Procedure for training graduates of the degree of Doctor of Philosophy and Doctor of Science in higher educational institutions (scientific institutions)"]. (n.d.). zakon.rada.gov.ua. Retrieved from https://zakon.rada.gov.ua/laws/show/261-2016-\%D0\%BF\#Text [in Ukrainian]

4. Ministerstvo osviti i nauki Ukrä̈ni. Fond nacional'nih doslidzhen'. [Ministry of Education and Science of Ukraine. National Research Foundation]. Retrieved from https://mon.gov.ua/ua/nauka/nauka/ nacionalnij-fond-doslidzhen [in Ukrainian].

5. Vashhenko, L. M. (2005). Upravlinnja innovacijnimi procesami v zagal'nij serednij osviti [Management of innovation processes in general secondary education in the region]. $K$. : Vidavniche ob'ednannja «Tirazh» [in Ukrainian].

6. Strategichnij plan dijal'nosti ministerstva osviti $i$ nauki Ukrä̈ni do 2024 roku vid 19.12.2019 [Strategic plan of the Ministry of Education and Science of Ukraine until 2024]. Retrieved from https://mon.gov.ua/storage/app/media/news/\%D0\%9D\%D0\%BE\%D0\%B2\% D0\%B8\%D0\%BD\%D0\%B8/2020/01/strat_plan_mon_2024.pdf [in Ukrainian].

7. Osvitn'o-naukova programa pidgotovki doktoriv filosofii $v$ aspiranturi Harkivs'koi medichnoï akademiï pisljadiplomnoï osviti z medichnih nauk za special'nistju 222 - Medicina [Educational and scientific program of training doctors of philosophy in graduate school of Kharkiv Medical Academy of Postgraduate Education in Medical Sciences, specialty 222 Medicine]. Retrieved from https://drive.google.com/file/d/1MydGJkTM8cX5SGgt6CuUEmfA 5tMHK3RI/view [in Ukrainian].

8. Osvitn'o-naukova programa pidgotovki doktoriv filosofii v aspiranturi Harkivs'koï medichnoï akademiï pisljadiplomnoï osviti z medichnih nauk za special'nistju 228 - Pediatrija [Educational and scientific program of training doctors of philosophy in graduate school of Kharkiv Medical Academy of Postgraduate Education in Medical Sciences, specialty 228]. - Retrieved from https://drive.google.com/file/d/1JxULj_f9JVLxRiE0x3AHwF6RSh0KsUn1/view [in Ukrainian].

9. Kas'janova, O. M. (2021). Teoretiko-metodologichni osnovi innovacijnoï pedagogiki [Theoretical and methodological foundations of innovative pedagogy]. Harkiv : HMAPO [in Ukrainian]. 